\title{
Effect of Pre-storage pulsing treatments on floret longevity in cut spikes of gladiolus (Gladiolus grandiflora L.) cv. White prosperity
}

\author{
Virendra Pal ${ }^{1}$, Ashish Tyagi ${ }^{2}$ and Mani Ram $^{3}$ \\ ${ }^{1 \& 2}$ Krishi Vigyan Kendra, Hastinapur, SVP Univ. of Agric. \& Tech. Meerut- 250110 (U.P.) \\ ${ }^{3}$ Department of Horticulture, SVP Univ. of Agric. \& Tech. Meerut- 250110 (U.P.)
}

\begin{abstract}
An experiment was conducted to analyze the effect of pre-storage pulsing treatments consisted of sucrose (3\%), Aluminium sulphate $(100 \mathrm{ppm})$ and $200 \mathrm{ppm}$ and Copper sulphate $(100 \mathrm{ppm})$ on the storage vase life and quality of gladiolus cv. white prosperity cut spikes. The pulsing treatment spikes with $3 \%$ sucrose in the combination treatments with aluminium sulphate $(100 \mathrm{ppm})$ and copper sulphate $(100 \mathrm{ppm})$ resulted in strong vase life ( 8.15 days), floret diameter $(10.28 \mathrm{~cm})$, floret longevity $(4.27$ days $)$ and per cent opening of florets (85.61) over the other treatments. The pulsed gladiolus spikes, wet stored under refrigerated conditions showed that decline in vase life, floret longevity, per cent floret opening and per cent increased in fresh weight. Fresh spikes are showed that the maximum vase life than stored under refrigerated conditions for various deviations. In wet stored cut spikes, maximum vase life was recorded after three days storage duration while minimum after 21 days storage duration. The pulsed gladiolus cut spikes could be pre stored at $5-6{ }^{\circ} \mathrm{C}$ refrigerated temperature for 10 days without reduction in vase life.
\end{abstract}

Keywords: Sucrose, Aluminium sulphate, Copper sulphate, Pulsing and Storage life.

Paper cited: Pal, V., Tyagi, A. and Ram, M. (2015). Effect of Pre-storage pulsing treatments on floret longevity in cut spikes of gladiolus (Gladiolus grandiflora L.) cv. White prosperity. South Asian Journal of Food Technology and Environment, 1(3\&4): 279-283.

\section{Received: 10/11/2015 Revised: 23/11/2015 Accepted 27/11/2015}

\section{Introduction}

Gladiolus, an important bulbous ornamental is commercially grown in India for the production of cut spikes. It is very much liked for its majestic spikes containing attractive, elegant and delicate florets. There is a demand of gladiolus cut spikes round the year. Quality of the spikes has direct bearing on its keeping quality. (Singh et al., 2001b) have reported that longer spikes exhibited required of sucrose in vase solution. The development stage of the floret at the time of harvest also considerably influences keeping quality of the spikes (Singh et al, 2010). It was considered of interested study if the spikes of various quality provinces from the uniform sized corms cold very in the accumulation of carbohydrates and keeping quality. The storage of gladiolus cut spikes holds consideration utility to regulate the market supply for maintaining of the price stability. The gladiolus growers face considerable problem in marketing of spikes, especially during the period of gluts when there a surplus produce and demand is low. The present study conducted on the effect of quality and harvest on keeping quality of cut gladiolus spikes in relation to the endogenous levels of carbohydrates.

\section{Materials and methods}

The present investigation was carried out in the Department of Horticulture, Horticulture Research Centre (HRC), S.V.P. University of Agriculture and Technology, Meerut during the 2008-09. The experiment was laid out in factorial completely randomized block design with 3 pulsing treatments, 5 storage duration, 5 replications and 5 number of spikes per replication. The healthy and uniform spikes were harvested at height bud stage (when basal 1-2 florets showed colour) and were immediately put in buckets containing water. The cut spikes were made into bundles of 3 each and treated with 
three pulsing solutions for $24 \mathrm{~h}$ before storage. The pulsing treatments were consisted of sucrose, aluminium sulphate and copper sulphate in various combinations viz. $3 \%$ sucrose $+100 \mathrm{ppm}$ aluminium sulphate $\left(\mathrm{T}_{1}\right)$; $3 \%$ sucrose $+200 \mathrm{ppm}$ aluminium sulphate $\left(\mathrm{T}_{2}\right) ; 3 \%$ sucrose +100 ppm copper sulphate $\left(\mathrm{T}_{3}\right)$; control (distilled water) $\left(\mathrm{T}_{4}\right)$. After $24 \mathrm{~h}$, the collective fresh weight of cut spikes was recorded and these were wet storage under refrigerated conditions $\left(5-6{ }^{\circ} \mathrm{C}\right)$ temperature and $85-90 \%$ relative humidity) with their basal 6-8 cm stem dipping in water for $0\left(\mathrm{~S}_{0}\right) 3\left(\mathrm{~S}_{1}\right)$, $6\left(\mathrm{~S}_{2}\right), 9\left(\mathrm{~S}_{3}\right) 12\left(\mathrm{~S}_{4}\right)$ and $15\left(\mathrm{~S}_{5}\right)$ day in cool chamber. After storage, the height of spikes was recorded and lower $2 \mathrm{~cm}$ spike portions were re-cut and spikes were kept in conical glass, containing distilled water. Data on various parameters were recorded and analyzed statistically (Table 1 to 4 ).

\section{Results and discussion}

It is evident from Table 1 , that storage durations, pulse treatments and significant influences on number of days to opening of basal floret in gladiolus spikes. The minimum (0.00) number of days to opening of basal floret was observed in $\mathrm{S}_{5}$ storage duration (15 days) and maximum (3.61) in $\mathrm{S}_{0}$ storage duration ( 0 days). The pulse treatment $\mathrm{T}_{3}(3 \%$ sucrose +200 ppm aluminium sulphate) took minimum (2.41) number of days for floret opening while the maximum (3.53) days to open basal floret were recorded in $T_{4}$ treatment. As far as interaction in concerned, the minimum (0.00) number of days to opening of basal floret was found in $\mathrm{S}_{5} \mathrm{~T}_{1}$, $\mathrm{S}_{5} \mathrm{~T}_{2}, \mathrm{~S}_{5} \mathrm{~T}_{3}$ and $\mathrm{S}_{6} \mathrm{~T}_{4}$ treatment combinations, whereas the maximum (4.17) number of days to opening basal floret was recorded in $\mathrm{S}_{0} \mathrm{~T}_{4}$ treatment combination. Days taken for basal floret to open decreased with increased in storage duration. It seems that the less number of days to open basal floret obtained number $\mathrm{T}_{3}$ might be due to higher soluble sugar in the buds and cell division or cell elongation by copper sulphate and $\mathrm{GA}_{3}$. These results are in agreement with the findings of (De et $a l$., 1996; Goszcznska and Ridnicki, 1990).

Table 1: Effect of pre-storage pulsing treatment on days to opening of basal floret in cut spikes of gladiolus cv. white prosperity.

\begin{tabular}{|c|c|c|c|c|c|}
\hline \multirow{2}{*}{$\begin{array}{c}\text { Storage duration } \\
\text { (Day) }(\mathbf{S})\end{array}$} & \multicolumn{4}{|c|}{ Pulsing treatments } & \multirow{2}{*}{ Mean } \\
\cline { 2 - 5 } & $\mathbf{T}_{\mathbf{1}}$ & $\mathbf{T}_{\mathbf{2}}$ & $\mathbf{T}_{\mathbf{3}}$ & $\mathbf{T}_{\mathbf{4}}$ & \\
\hline $\mathrm{S}_{0}$ & 3.82 & 3.24 & 3.20 & 4.17 & 3.61 \\
\hline $\mathrm{S}_{1}$ & 3.79 & 3.06 & 2.89 & 3.88 & 3.40 \\
\hline $\mathrm{S}_{2}$ & 3.31 & 3.00 & 2.75 & 3.80 & 3.22 \\
\hline $\mathrm{S}_{3}$ & 3.21 & 2.84 & 2.72 & 3.28 & 3.01 \\
\hline $\mathrm{S}_{4}$ & 3.06 & 2.14 & 2.52 & 3.10 & 2.70 \\
\hline $\mathrm{S}_{5}$ & 2.54 & 0.60 & 0.40 & 3.00 & 1.63 \\
\hline Mean & 3.28 & 2.48 & 2.41 & 3.53 & \\
\hline
\end{tabular}

C.D. $(\mathrm{P}=0.05)$ storage duration $(\mathrm{S})$, pulsing treatment $(\mathrm{T}) \&$ storage duration $\mathrm{x}$ pulsing treatment $(\mathrm{S} \times \mathrm{T})$

From Table 2, it is clear that the pulsing treatments, storage durations and there had significant influences on the cut spikes vase life. The maximum (6.65 days) vase life was observed in $\mathrm{S}_{0}$ storage duration, which it was at par with $S_{1}$ and $S_{2}$, whereas the rapid decrease in vase life was observed after 12 days storage $\left(\mathrm{S}_{4}\right)$. The maximum (7.29 days) 
vase life was observed in $\mathrm{T}_{3}(3 \%$ sucrose + $200 \mathrm{ppm}$ aluminum sulphate treatment, while minimum (3.97 days) in $\mathrm{T}_{4}$ (control) treatment. Vase life decreased with the increase in storage duration might be due to fact process to development and senescence, continue slowly, leading to raid senescence after storage. The higher vase life was observed $\mathrm{T}_{3}$ might due to exogenous supply of sucrose which replaced the depleted endogenous carbohydrates utilized during the post harvest life of flowers (Singh and Sharma, 2003).

Table 3 revealed that storage duration, pulsing treatments and their interaction had a significant effect on floret diameter. The maximum $(9.50 \mathrm{~cm})$ floret diameter was observed in $S_{0}$ ( 0 day) storage duration, whereas the minimum (7.78 days) in $\mathrm{S}_{5}(21$ day) storage duration. It was found that floret diameter decreased with increase in duration of storage. The minimum $(8.46 \mathrm{~cm})$ floret diameter was recorded in $\mathrm{T}_{3}(3 \%$ sucrose + $200 \mathrm{ppm}$ aluminium sulphate) treatment. As far as interaction is concerned, the maximum $(10.18 \mathrm{~cm})$ floret diameter was observed in $\mathrm{S}_{0} \mathrm{~T}_{3}$ treatment combination while minimum $(6.74 \mathrm{~cm})$ in $\mathrm{S}_{5} \mathrm{~T}_{4}$ treatment combination. These results are in agreement with the findings of (Singh and Sharma, 2003) in gladiolus, who also reported that floret diameter of gladiolus was improved with pulsing solution of sucrose and aluminium sulphate over control.

Table 4 indicated that the maximum (3.44) floret longevity was found in $S_{0}$ (0 day) storage duration, while, the minimum (2.35) in $\mathrm{S}_{5}$ (21 day storage duration. The pulsing treatment $\mathrm{T}_{3}(3 \%$ sucrose $+200 \mathrm{pm}$ aluminium sulphate resulted in maximum (3.20) floret longevity, while minimum (2.07) floret longevity was observed in $\mathrm{T}_{4}$ (control) treatment. Interaction data show that the maximum (4.18) floret longevity was recorded in $\mathrm{S}_{0} \mathrm{~T}_{3}$ treatment combination, while, the minimum (0.00) in $\mathrm{S}_{5} \mathrm{~T}_{4}$ treatment combination. Pre storage pulsing treatment significantly increased the number of florets open at a time which clearly indicated that sucrose + aluminium application before storage increased the floret longevity. The increase in floret longevity by mineral salts might be due to the fact that mineral salt increased the osmotic concentration and pressure potential of the petal cells thus improving their water uptake. The increase in floret diameter and floret longevity might be due to continuous absorption of water, regular supply of carbohydrates, antimicrobial activity of aluminium sulphate and low $\mathrm{pH}$ of the solution. Similarly, wet refrigerated storage of gladiolus enhanced the floret longevity compared with cut flowers kept at ambient temperatures (De and Bhattacharya, 1997).

Table 2: Effect of pre-storage pulsing treatment on vase life (day) in cut spikes of gladiolus cv. white prosperity.

\begin{tabular}{|c|c|c|c|c|c|}
\hline $\begin{array}{c}\text { Storage duration } \\
\text { (Day) }(\mathbf{S})\end{array}$ & \multicolumn{3}{|l|}{ Pulsing treatments } & \multirow{2}{*}{ Mean } \\
\cline { 2 - 5 } $\mathbf{T}_{\mathbf{1}}$ & $\mathbf{T}_{\mathbf{2}}$ & $\mathbf{T}_{\mathbf{3}}$ & $\mathbf{T}_{\mathbf{4}}$ & \\
\hline $\mathrm{S}_{0}$ & 6.72 & 7.69 & 7.86 & 4.35 & 6.65 \\
\hline $\mathrm{S}_{1}$ & 6.70 & 7.54 & 7.66 & 4.62 & 6.63 \\
\hline $\mathrm{S}_{2}$ & 6.63 & 7.51 & 7.61 & 4.22 & 6.49 \\
\hline $\mathrm{S}_{3}$ & 6.31 & 7.06 & 7.10 & 3.87 & 6.01 \\
\hline $\mathrm{S}_{4}$ & 5.86 & 6.43 & 6.88 & 3.58 & 5.68 \\
\hline $\mathrm{S}_{5}$ & 5.8 & 6.44 & 6.67 & 3.21 & 5.53 \\
\hline Mean & 6.33 & 7.11 & 7.29 & 3.97 & \\
\hline
\end{tabular}

C.D. $(\mathrm{P}=0.05)$ storage duration $(\mathrm{S})$, pulsing treatment $(\mathrm{T}) \&$ storage duration $\mathrm{x}$ pulsing treatment $(\mathrm{S} \times \mathrm{T})$ 
Table 3: Effect of pre-storage pulsing treatment on floret diameter $(\mathrm{cm})$ in cut spikes of gladiolus cv. white prosperity.

\begin{tabular}{|c|c|c|c|c|c|}
\hline \multirow{2}{*}{$\begin{array}{c}\text { Storage duration } \\
\text { (Day) (S) }\end{array}$} & \multicolumn{2}{|l|}{ Pulsing treatments } & \multirow{2}{*}{ Mean } \\
\cline { 2 - 5 } & $\mathbf{T}_{\mathbf{1}}$ & $\mathbf{T}_{\mathbf{2}}$ & $\mathbf{T}_{\mathbf{3}}$ & $\mathbf{T}_{\mathbf{4}}$ & \\
\hline $\mathrm{S}_{0}$ & 9.69 & 10.0 & 10.18 & 8.15 & 9.50 \\
\hline $\mathrm{S}_{1}$ & 9.21 & 9.80 & 9.70 & 7.41 & 9.02 \\
\hline $\mathrm{S}_{2}$ & 8.78 & 9.14 & 9.52 & 7.58 & 8.75 \\
\hline $\mathrm{S}_{3}$ & 8.61 & 8.96 & 9.21 & 7.21 & 8.49 \\
\hline $\mathrm{S}_{4}$ & 8.00 & 8.40 & 8.84 & 6.92 & 8.04 \\
\hline $\mathrm{S}_{5}$ & 7.66 & 8.26 & 8.46 & 6.74 & 7.78 \\
\hline Mean & 8.65 & 9.09 & 9.31 & 7.33 & \\
\hline
\end{tabular}

C.D. $(P=0.05)$ storage duration $(S), 0.19$, pulsing treatment $(\mathrm{T}) 0.14:$ storage duration $x$ pulsing treatment $(\mathrm{S} \times \mathrm{T}): 0.39$

Table 4: Effect of pre-storage pulsing treatment on floret longevity in cut spikes of gladiolus cv. white prosperity

\begin{tabular}{|c|c|c|c|c|c|}
\hline \multirow{2}{*}{ Storage duration (Day) (S) } & \multicolumn{3}{|l|}{ Pulsing treatments } & \multirow{2}{*}{ Mean } \\
\cline { 2 - 5 } & $\mathbf{T}_{\mathbf{1}}$ & $\mathbf{T}_{\mathbf{2}}$ & $\mathbf{T}_{\mathbf{3}}$ & $\mathbf{T}_{\mathbf{4}}$ & \\
\hline $\mathrm{S}_{0}$ & 3.10 & 3.62 & 4.18 & 2.86 & 3.44 \\
\hline $\mathrm{S}_{1}$ & 2.90 & 3.22 & 3.42 & 2.66 & 3.06 \\
\hline $\mathrm{S}_{2}$ & 2.83 & 3.06 & 3.30 & 2.52 & 2.92 \\
\hline $\mathrm{S}_{3}$ & 2.58 & 2.77 & 3.10 & 2.26 & 2.67 \\
\hline $\mathrm{S}_{4}$ & 2.36 & 2.74 & 2.70 & 2.10 & 2.47 \\
\hline $\mathrm{S}_{5}$ & 2.31 & 2.51 & 2.51 & 2.07 & 2.35 \\
\hline Mean & 2.60 & 2.98 & 3.20 & 2.41 & \\
\hline
\end{tabular}

C.D. $(P=0.05)$ storage duration $(S) 0.17$, pulsing treatment $(\mathrm{T}) 0.12 \&$ storage duration $\mathrm{x}$ pulsing treatment $(\mathrm{S} \times \mathrm{T}) 0.34$

\section{Conclusion}

The chemical combinations of $(3 \%$ sucrose $+200 \mathrm{ppm}$ aluminium sulphate) have been found that best floral pre - storage pulsing treatment for enhancing the vase life and keeping quality of gladiolus cv. white prosperity and cut spikes can be stored upto 12 day without any reduction in vase life and floret quality.

\section{References}

1. De, L.C. and Bhattacherjee, S.K. (1997). Post harvest life of cut gladiolus spikes as affected by cold storage. Annals of Plant Physiology, 11(1): 39-44.

2. De. L.C., Bhattacharjee, S.K. and Misra, R.L. (1996). Post harvest life of pulsed gladiolus spikes as affected by different chemicals. Journal of Ornamental Horticulture, 4(1-2): 18-22.

3. Goszcznska, D. and Ridnicki, R.M. (1990). Storage of cut flowers. Horticultural Review, 10: 35-62.

4. Kofranek, A.M. and Halevy, A.H. (1976). Sucrose pulsing of gladiolus stems before storage to increase spike quality. Horticultural Science, 11: 572573.

5. Singh, K. and Arora, J.S. (2000). Effect of cultivar response, season, stage of harvest and sucrose on keeping quality of gladiolus. Proceeding of National Conference on gladiolus held at NBRI, Lucknow (UP) during 19-20 January, 2000. No. 38.

6. Singh, P.V. and Sharma, M. (2003). The post harvest life of pulsed gladiolus 
spikes, the effect of preservation solutions. Acta Horticulturae, 624: 395398.

7. Singh, K.P., Singh, J., Arora, J.S. and Mann, R.P.S. (2001). Effect of vase life collection on keeping quality of spikes of different categories of gladiolus. Journal of Plant science Research, 19: 23.25 .

8. Singh, K., Kumar, R. and Singh, R. (2010). Effect of stages of harvest on wet refrigerated storage of gladiolus spikes. Proceeding of National Symposium on life style floriculture; challenges and opportunities, Dr. Y.S. Parmer Univ. of Hort. and Forestry. Nauni, Solan P. 152. 